УДК 78.24

\title{
I. Ельтек \\ ЕВОЛЮЦІЯ ТРАКТУВАННЯ ПОЕЗІЇ ІВАНА ФРАНКА У ТВОРЧОСТІ МИРОСЛАВА СКОРИКА: ВІД НЕОФОЛЬКЛОРИЗМУ ДО ЕГАЛІТАРИЗМУ
}

Одним з послідовних інтерпретаторів поезії І. Франка є Мирослав Скорик. Діалог мистиів почався з кантати «Весна», симфонічно-хореографічної поеми «Каменярі», а кульмінаційним етапом стала опера «Мойсей». Герменевтичний аналіз цих опусів дозволив узагальнити наступні ї характеристики: узгодження «високого» $i$ «популярного», «модерну» $i$ «традиції, що характерно для позицій «егалітарного» мистеитва; значне ускладнення музичної мови. Музична франкіана М. Скорика відкрила нові тенденції у трактуванні філософських значень франкової поезії для майбутніх поколінь композиторів.

Ключові слова: Іван Франко, егалітаризм, музична франкіана, Мирослав Скорик.

Творча постать Івана Франка становить невід’ємну складову української та європейської культури. Його філософська, публіцистична, художня спадщина та роль у розвитку суспільно-політичної думки залишається актуальною і важливою для національного самоусвідомлення українців на сучасному етапі утвердження української національної ідентичності в межах самої держави та інтеграція цієї держави в світовій спільноті.

У 60-х рр. ХХ століття в творчості львівських композиторів спостерігається оновлення системи музичного мислення, пов'язане 3 переосмисленням естетичних орієнтирів та прагненням вписати галицьку, а ширше - українську культуру, в західноєвропейський контекст. Більш як через сто років галицькі композитори знову віднаходять в особі І. Франка свого духовного поводиря і наставника. Злам художньої свідомості, багатоманітність композиторських технік та діалог різних стильових епох сприяли значному збагаченню музичної франкіани кінця XX - початку XXI століття якісно новими прочитаннями та переосмисленням франкового слова у сучасному вимірі. У творчості сучасного львівського композитора, Героя України, лауреата Національної премії України ім. Т. Шевченка Мирослава Скорика франкове слово віднайшло своє «друге дихання», а його прочитання суттєво відрізняється від більшості «радянських штампів» чи примітизованих так званих «патріотичних» шаблонів.

(C) Ельтек I., 2015 
Актуальні аспекти музичної інтерпретації поезії І. Франка найбільш грунтовно висвітлені у музикознавчих працях С. Людкевича, М. Загайкевич, С. Павлишин, Л. Кияновської, А. Терещенко; також окремі положення розглядаються в розвідках О. Козаренка, Л. Яросевич, Л. Пархоменко, Я. Якуб'яка. Проте питання музичної франкіани кінця XX - початку XXI ст. знайшло здебільшого фрагментарне наукове втілення у вищеперелічених працях, серед яких послідовно до висвітлення цієї теми зверталася Л. Кияновська. Для дослідження філософського спектру образів та символіки поезії І. Франка, авторка послуговувалася літературознавчими працями Я. Грицака [2], О. Забужко [3], Я. Гарасима [1], В. Щурата [11] та багатьох інших.

Отже, основою для грунтовного висвітлення поставленого у статті питання є детальний аналіз літературного першоджерела та відстеження основних аспектів композиторського прочитання семантичних кодів, що лягли в основу філософських концептів франкової поезії.

Мистецький рух, пов'язаний 3 «примірянням» нових естетичних орієнтирів, пошуком компромісу між «високим» i «популярним» у мистецтві, спрямував творчу генезу львівської композиторської школи кінця XX - початку XXI століть на пошук сучасної інтерпретації франкового слова, що відповідав би вимогам нового українського суспільства.

Найбільш глибинним та послідовним інтерпретатором поетичного світу I. Франка є, беззаперечно, Мирослав Скорик. Цей діалог двох мистців, двох епох почався вже з дипломної роботи Мирослава Скорика, а саме - кантати «Весна», яку він написав у 1960 р. при закінченні Львівської консерваторії (нині - Львівської національної музичної академії ім. М. Лисенка) в класі Адама Солтиса. Цим твором, який викликав неабиякий резонанс в мистецькому житті навчального закладу, автор ще достатньо близький до усталених традицій галицької музичної франкіани.

Цей твір став початком тривалого процесу у становленні індивідуального стилю композитора, що формувався під призмою «нової фольклорної хвилі» і повністю розкрився у творах другої половини 60-х років. Проте навіть в цій ранній спробі композиторського пера М. Скорик вже засвідчує певні риси індивідуальної манери письма, особливості своєї художньої системи та нове сприйняття поетичної філософії видатного поета.

Композитор вибрав п’ять поезій із циклу «Веснянки» (збірка «3 вершин і низин»), які, в алегоричній формі, змальовують не просто 
весняне пробудження природи, а «весну цілого народу». Так, перший вірш «Дивувалась зима» - це пробудження народу та радісне очікування приходу самої весни. Наступна поезія «Гримить», у якій «мільйони чекають щасливої зміни» дає усвідомлення того, що цей прихід неможливий без грому та першої весняної грози, з якої і повинен з'явитися благодатний дощ, щоб скропити суху землю. Третій вірш «Встань, орачу, встань» - це заклик про те, що настала пора національній інтелігенції сіяти «золоте зерно», а народу - «не проспати» благодатного врожаю («Гей, брати! В кого серце чистеє, руки сильнії, думка чесная, - прокидайтеся!»). Продовжують цю сюжетну фабулу четвертий та п’ятий вірші, які промовляють до українського народу — «Зеленійся, рідне поле, українська ниво» та «Земле моя, всеплодющая мати», де у символічному єднанні народу і землі прихований генетичний код нації - українців-землеробів. 3 огляду цього прочитання Франкової поезії М. Скорик притримується відповідного музично-виразового шляху.

Свідомо оминаючи детальний музично-теоретичний аналіз кантати «Весна» ${ }^{1}$, зупинимося на окресленні цікавих композиторських знахідок в музичному прочитанні поезії І. Франка. Однією з них, насамперед, є використання М. Скориком різноманітних звукозображальних ефектів для підсилення символічних Франкових рядків. Так, в I частині - подув вітерця на словах «Шуря-буря пройшла» супроводжують бурхливі пасажі у супроводі до теми, що поступово згасають, «пролітаючи» геть; «подих уст ледяних» ефектно імітує хроматизована висхідна гама в партії скрипок. Початкова тема-заклик «Гримить» з II частини завдяки прийому імітаційної поліфонії отримує ефект відлуння, а вже в III частині - затримання останніх нот основного мотиву в оркестровій партії створює просторовий ефект звуку, що «несеться» в повітрі. В IV частині на словах «оживає природа» композитор використовує своєрідні ладотональні прийоми, що створюють неповторний звукозображальний ефект. Навіть на рівні композиційної структури окремих частин та драматургії загалом М. Скорик досягає близької спорідненості із літературним джерелом: I частина варіантно-варіаційна форма - традиційна для українських народних пісень, що підкреслює фольклорне начало; II частина - ознаки рондальної та варіантно-куплетної форми, яка змальовує кілька кіл весняної грози-боротьби; III частина - скерцо, яке передає радісний настрій весняної природи; IV частина - подвійна фуга з двох тем-

\footnotetext{
${ }^{1}$ Аналіз даного твору у найповнішій його версії подає Л. Кияновська у монографії «Мирослав Скорик: людина і митець» (Львів, 2008).
} 
перша змальовує як «оживає природа», а друга - нагадує за своєю структурою та інтонацією гаївку; V частина - контрастно-складена, в ній проводяться ремінісценції з попередніх частин, що є об'єднуючим чинником циклічної структури кантати.

На противагу поширеному твердженню в радянський час про те, що патріотизм повинен бути окреслений лише традиційними виразовими засобами в музиці, спрямований до «масового» слухача М. Скорик вже у першому зверненні до поезії І. Франка не тільки подолав загальні штампи, які склалися в суспільстві, а й зумів реабілітувати та винести до широкої аудиторії правдиве філософське значення Франкового слова.

Симфонічно-хореографічна поема «Каменярі» написана композитором у 1967 р. на лібрето В. Народенка, апелює до ще однієї сторінки в творчості І. Франка, «революційно-конфліктної» як стверджувалось радянськими франкознавцями. Проте яскраво-символічний зміст музики М. Скорика вже вдруге наштовхує слухача на нові естетично одухотворені рефлексії, що не вписуються у рамки заниженої радянським трактуванням революційної прикмети поезії Івана Франка. Як зазначає Марія Загайкевич: «Балет «Каменярі» вперше був поставлений у 1967 році у Львові як частина балетної трилогії «Досвітні вогні»» [4, 168]. Ідейним задумом і водночас організуючим чинником цієї трилогії була тематична спрямованість поезії Тараса Шевченка, Івана Франка та Лесі Українки (які були літературним підгрунтям) до свідомості українського народу та закликом до пробудження з «кам'яного сну». Проте балет «Каменярі» вже наступного року у виконанні трупи Київського академічного театру опери і балету ім. Т. Шевченка (балетмейстер - А. Шекера) заявив про себе як цілком завершений та самодостатній твір.

Незвична як для балету не лише форма симфонічної поеми, побудованої за принципами сонатного allegro. Композитор відмовляється від елементів танцювальної жанровості і конкретно-зображального звукопису, характерних для балетної манери письма, натомість використовує емоційно-експресивну музичну мову, притаманну, здебільшого, драматичному симфонізму. Це дозволило М. Скорику розвіяти певний поверхнево-революційний німб, який стільки років нависав над поемою «Каменярі». Вже у повільному вступі похмура тема фагота, яка фактично є лейттемою усього твору, змальовує той «дивний сон», у якому пусті та дещо «приглушені» октави в партії контрабасів та арфи досягають ефекту просторовості, вторуючи картині, яка від- 
кривається перед Франком у цьому сновидінні, а саме - «безмірна, пуста і дика площина». Інтонаційна спільність цієї лейттеми з усіма іншими створює один узагальнюючий образ каменярів, у якому кожна наступна тема лише поглиблює центральний образ балету. Друга тема вступу у партії віолончелей та альтів не тільки просвітлює образ, але й гострим синкопованим ритмом активізує початковий рух, скидаючи з себе «добровільні пута», через які невольники стали «рабами волі».

Основна частина твору відразу розпочинається динамічним розвитком ритмічно загостреної теми невтомної праці-боротьби, яка виступає першою темою головної партії. Її характерна ритмоформула «нависатиме» над практично усіма вузловими місцями поеми. Друга тема головної партії, без сумніву, інспірована наступними рядками Івана Франка: «І всі ми, як один, підняли вгору руки, I тисяч молотів о камінь загуло, І в тисячні боки розприскалися штуки Та відривки скали; ми з силою розпуки Раз по раз гримали о кам'яне чоло». Кожна перша доля цієї вольової та цілеспрямованої рельєфної теми супроводжується тяжкими «ударами» акордів. Побудована на тембровому чергуванні труб та струнних, у своєму кульмінаційному зламі вона готує появу побічної партії, яка вступає без будь-якої попередньої підготовки-зв'язки. Ця напрочуд лірична тема уособлює жіноче начало в симфонічній поемі та кореспондує до таких рядків поета: «І знали ми, що там далеко десь у світі, Який ми кинули для праці, поту й пут, За нами сльози ллють мами, жінки і діти». У балеті цей образ підсилений появою на сцені жінок-плакальниць, які символічно єднаються у траурний танок. Завершується експозиція поверненням головної теми вступу як драматичне підсилення образу каменярів, які готуються до вирішального бою.

Розробка поеми постає на перетині крайньої драматизації музичного вислову та грандіозного внутрішнього нагнітання, що видається нам найбільш співзвучним з рельєфною картиною, яку так змальовує I. Франко: «Мов водопаду рев, мов битви гук кривавий, Так наші молоти гриміли раз у раз; I п'ядь за п'ядею ми місця здобували; Хоч не одного там калічили ті скали, Ми далі йшли, ніщо не спинювало нас». Несподіваним моментом в розробці і в так званій точці «золотого перетину» є поява нової маршової теми, яка близька своїм образним тематизмом та наступальним рухом до «теми нашестя» із симфонії Д. Шостаковича. В досліджуваному творі - це так звана «тема прокляття», яким нагороджують «други й недруги, гнівнії та сердиті»і каменярів, «і намір наш, і діло». 
Реприза є основною кульмінацією усієї поеми та найвищим композиторським втіленням Франкового задуму: «Нехай прокляті ми і світом позабуті! Ми ломимо скалу, рівняєм правді путі, І щастя всіх прийде по наших аж кістках». На вершині цього звукового водоспаду опиняється друга тема головної партії, що проводиться унісоном всього оркестру. Останні дисонантні акорди на fff, як символ останніх ударів каменярів, обриваються ще одним раптовим ріапо. На фоні схвильовано-скорботного тремоло струнних звучить побічна партія у флейти, а потім - гобоя - як трагічний образ усіх матерів, овдовілих жінок, осиротілих дітей, та й самої України, яка залишилася без своїх героїв-каменярів.

У цьому високодуховному та ідейно-філософському прочитанні поезії «Каменярі» I. Франка Мирослав Скорик першим наблизився до розуміння «золотого зерна» антропоцентричної філософії світу, яку так бережно плекав український поет на рідній землі в контексті майбутнього національного відродження.

Опера «Мойсей», написана на лібрето Богдана Стельмаха (2000р.), стала тією «обітованою землею», до якої протягом сорока років простував дорогу сам М. Скорик і привів на ії простори весь український народ, а окрім того втілив в життя два найважливіші заповіти - свого батька та I. Франка, котрий пробудив таки національну інтелігенцію для визнання української самості у європейській культурі. Прем'єра цього твору відбулася з Папського благословення 23 червня 2001 p. під керівництвом автора у Львівському академічному театрі опери і балету ім. С. Крушельницької. У монографії Любові Кияновської «Мирослав Скорик: людина і митець» [6] подається розгорнутий аналітичний аналіз опери. Тому у даній статті ми першочергово зосередилися на проблемах інтерпретаційної відповідності та розбіжності у філософських прочитаннях Івана Франка та Мирослава Скорика.

Жанрова основа опери - опера-притча, яка «за типом побудови наближена до опери-ораторії» [6, 507]. Загальна структура опери пролог, дві дії та епілог. Розглядаючи два мистецькі підходи до трактування біблійного сюжету, ми визначимо спільність та відмінність у цих прочитаннях та, що важливо, в контексті досліджуваної нами теми, - музичну інтерпретацію поеми І. Франка «Мойсей». Так, в опері з'являються сцени, які не мають конкретного літературного окреслення в поетичному творі. Це сцена любові Лії і Егошуа «Світанок» та сцена із золотим тільцем із I дії, які ввелися лібретистом і композитором саме з позицій оперного мислення. 
Особливості трактування біблійного сюжета у літературній інтерпретації І. Франка та музичній - М. Скорика прослідковуємо вже у характеристиці головних образів. Образ Мойсея у поемі I. Франка складається з трьох основних аспектів: біблійний пророк, духовний «будитель» нації, автобіографічний образ самого I. Франка (в пізньоромантичному трактуванні Поет-Месія). В музичному прочитанні М. Скорика зберігається триєдиність образу з позиції «універсальний - національний - індивідуальний», проте на відміну від I. Франка, акцент на перших двох позиціях та чіткий розподіл між Поетом та Пророком.

Алегорія франкового образу народу, до якого звертається Мойсей, полягає у потрійному значенні, поданому поетом для осмислення цього образу: ізраїльський народ; український народ; народ як окрема спільнота національної інтелігенції, в серце якої Бог вклав «творчі сили», що гнатимуть іiї у «призначене місто». Зазначимо, що в поемі є ще образ дітей, до яких промовляє Мойсей і які «так слухати раді». Це образ вже майбутнього покоління. М. Скорик формує свій об'єктивний погляд на тенденції, які притаманні сучасному глобалізованому суспільству на початку XXI століття: протистояння «земного і небесного» в духовному світі людини; суб'єктивна візія національного первня в опері, ледь виражені алюзії до національного «музичного словника»; розуміння образу народу як всезагального на сучасному етапі розвитку людства, звідси - тяжіння до самоіндетифікації та самопізнання (чого немає в літературному джерелі).

Устами «темних сил» (реальних - Авірон і Датан, потойбічних Азазель і лжематір Йохаведда) I. Франко відкриває перед народом «страшне майбутнє України XX ст., включно з Голодомором 19321933 років, «розстріляним Відродженням» національної інтелігенції, Соловками і війнами» $[6,525]$. В характеристиці «темних» сил композитор застосовує розгалужену лейтмотивну систему та різноманітні виразові прийоми: лейтмотив зневіри і сумнівів Авірона (ламанодисонантні мелодичні лінії та обірвані фрази) часто супроводжується лейттембром труби, яка характеризує «злі» сили; звуконаслідування «сичання гадюк», що проілюстроване оркестровими барвами; «діатоніка-хроматика» підкреслює протистояння «Мойсей-Азазель» у сцені спокуси. Поява Бога знаменує в поемі I. Франка та відповідно в опері М. Скорика не тільки драматургічну розв'язку, але й роль своєрідного заповіту самого поета та його бачення не легкого, проте світлого майбутнього України. Окрім того, композитор підкреслює 
зашифрований в поемі I. Франка код релігійно-символічного для християн усього світу числа «3». Це відображається і в трьох іпостасях Мойсея, і в потрійному трактуванні народу, в наскрізному розвитку тричастинної структури як в Пролозі, так і в центральній сцені Мойсея з I дії, а також - в трьох хвилях спокуси з II дії.

Індивідуальний стиль та творчий доробок композитора можна сміло співвіднести з постулатами «егалітаризму ${ }^{1}$ » сучасного мистецтва. Любов Кияновська засвідчує про «егалітаризм у музиці» як про «особливу світоглядну основу мистецького виразу, яка передбачає рівновагу між елітарним (високим, академічним) стилем і масовим демократичним способом вислову, що його здатна зрозуміти ширша аудиторія. Водночас, це мистецтво, що апелює до традиції, вступає 3 ним в діалог і трансформує в сучасних культурологічних вимірах різні, часто протилежні рівні свідомості та підходи» [7, 381].

Опера «Мойсей» засвідчує не тільки цілком новий етап у музичному прочитанні поезії Івана Франка, а й, повертаючись до витоків франкової філософії, є своєрідним «викликом» суспільству та вихідною точкою у переосмисленні своїх духовних, естетичних та ширше - національних цінностей у вирі глобалізованої метушні XXI століття. Ці категорії композитор послідовно втілив засобами музичного вислову на всіх рівнях музичної організації оперного полотна.

Аналітичний огляд та герменевтичний аналіз опусів М. Скорика на вірші І. Франка дозволив узагальнити наступні їх характеристики: узгодження «високого» і «популярного», «модерну» $\mathrm{i}$ «традиції», що характерно для позицій «егалітарного» мистецтва; суттєве ускладнення музичної мови; використання елементів «інтонаційного словника епохи» західноєвропейської музики кінця XIX - початку XX ст., тобто франкового часу.

Творчий геній Мирослава Скорика збагатив музичну франкіану кінця XX - початку XXI століття якісно сучасними інтерпретаціями, які знаменують «fin de sičcle» постмодернізму в українській музиці та, оперуючи новим терміном, стають першими зразками в ії «егалітарному» $[7,380]$ мистецтві. Специфіка композиторських акцентів, авторські концепції тлумачення поетичного слова та його символічного значення свідчать про семантично містке музичне прочитання та глибокий герменевтичний, структурний аналіз літературного першоджерела.

${ }^{1}$ Егалітаризм (фр. égalitarisme, від фр. égalité - рівність) - концепція, що пропонує створення суспільства з рівними можливостями з управління і доступу до матеріальних благ всім його членам. Протилежність елітаризму. 
Музична франкіана Мирослава Скорика не тільки продовжила тенденції музичної інтерпретації франкового слова, які склалися в галицькій музичній школі на кінець XX століття, а й відкрила нові обрії трактування філософських значень поезії I. Франка для майбутніх поколінь українських композиторів.

\section{СПИСОК ЛІТЕРАТУРИ}

1. Гарасим Я. Іван Франко: філософія національного поступу / Я. Гарасим // Українське літературознавство. - Львів, 2011. - Вип. 74. - С.12-19.

2. Грицак Я. Пророк у своїй вітчизні. Франко та його спільнота (18561886) / Ярослав Грицак // Критика. - Київ, 2006. - 631 с.

3. Забужко О. Філософія української ідеї та європейський контекст: франківський період / Оксана Забужко. - 2-ге вид. - К.: Факт, 2009. - 156 с. (Сер. «Висока полиця»).

4. Загайкевич М. Музичний світ великого Каменяра / М. Загайкевич. К.: Муз.Україна, 1986. - 175 с.

5. Кияновська Л. І. Франко, С. Людкевич, М. Скорик: три погляди на біблійного Мойсея / Л. Кияновська // Вісник Львівського університету. Серія: Мистецтвознавство. - Львів, 2006. - Вип. 6. - С. 79-88.

6. Кияновська Л. Мирослав Скорик: людина і митець / Любов Кияновська. - Львів, 2008. - 561 с.

7. Кияновська Л. Музичне прочитання поезії Івана Франка у вимірах сучасної естетики (на прикладі творчості львівських композиторів) / Л. Кияновська // Україна: культурна спадщина, національна свідомість, державність. Вип. 21: Scripta manent. Ювілейний збірник на пошану Богдана Якимовича / [гол. редколегії Микола Литвин; упоряд. Олександр Седляр, Наталя Кобрин]; Національна академія наук України, Інститут українознавства ім. І. Крип'якевича. - Львів, 2012. - С. 377-388.

8. Людкевич С. Іван Франко і музика / Станіслав Людкевич // Людкевич С. Дослідження, статті, рецензії, виступи / [упоряд. 3. Штундер]. - Львів: Вид-во М. Коць, 1999. - Т. 1. - С. 273-276.

9. Терещенко А. Музичні рефлексії до поезій І. Франка. Сучасний вимір / Алла Терещенко // Музична україністика: сучасний вимір: міжвідомчий зб. наук. ст. на пошану доктора мист-ва, професора Марії Загайкевич. - Київ, 2009. - Вип. 4. - С. 216-221.

10. Терещенко А. Кантати Мирослава Скорика / Алла Терещенко // Музична україністика: сучасний вимір: зб. наук.статей на пошану композиторки, кандидата мист-ва, заслуженої діячки мистецтв України Богдани Фільц. - Київ, 2010. - Вип. 5. - С. 152-160.

11. Щурат В. Франків спосіб творення / В. Щурат // Спогади про Івана Франка / [упоряд. М. Гнатюка]. - Львів: Каменяр, 1997. - С. 280-281. 
Ельтек И. Эволюция трактовки поэзии Ивана Франко в твориестве Мирослава Скорика: от неофольклоризма к эгалитаризму. Одним из последовательных интерпретаторов поэзии И. Франко является Мирослав Скорик. Диалог художников начался с кантаты «Весна», симфоническо-хореографической поэмы «Каменяри», а кульминационным этапом стала опера «Моисей». Герменевтический анализ этих опусов позволил обобщить следующие их характеристики: согласование «высокого» и «популярного», «модерна» и «традиции», что характерно для позиций «эгалитарного» искусства; значительное усложнение музыкального языка. Музыкальная франкиана М. Скорика открыла новые тенденции в трактовке философских значений поэзии Франко для будущих поколений композиторов.

Ключевые слова: Иван Франко, эгалитаризм, музыкальная франкиана, Мирослав Скорик.

Eltek I. Evolution of interpretation of Ivan Franko's poetry in Myroslav Skoryk's works: from neofolklorism to egalitarianism. One of the consecutive interpreters of I. Franko's poetry is Myroslav Skoryk. The dialogue between the two artists began with the cantata «Spring», symphonic choreographed poem «Stone Breakers», and the culminating step was the opera «Moses». Hermeneutic analysis of these opuses allowed to compile their following characteristics: harmonization of «high» and «popular», «modern» and «traditional», which is typical for positions of «egalitarian» art; significant complication of musical language. Musical frankiana of Skoryk opened a new trend in rendering philosophical meaning in Franko's poetry for future generations of composers.

Keywords: Ivan Franko, egalitarianism, music frankiana, Miroslav Skorik.

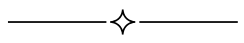

УДК 78.071.1+786.2

\section{Лю Кетин}

\section{ВЕРИЗМ-СИМВОЛИЗМ В ФОРТЕПИАННОМ ТВОРЧЕСТВЕ КОМПОЗИТОРОВ ОДЕССЫ 1950-х - 1960-х ГОДОВ (на примере произведений К. Данькевича и С. Орфеева)}

В работе освещаются на примерах творчества высокоталантливых одесских композиторов К. Данькевича и С. Орфеева, в анализе самых популярных в исполнительских и слушательских кругах их сочинений, стилевые касания, которые имели специальный культурный контекст сопряженности с музыкальными традициями Одессы, откликаясь, одновременно, на стилевую парадигматику украинского искусства в целом 